\title{
Transcatheter arterial chemoembolization combined with elemene for the treatment of hepatic carcinoma
}

\author{
Youjin Wang, Xianglei Shen, Shaoyi Huang, Jiaxun Zhou, Wengui Liu \\ Department of Interventional Radiology, Jiangsu Province Hospital of TCM, Nanjing University of Chinese Medicine, Nanjing 210029, China \\ Correspondence to: Wengui Liu. Department of Interventional Radiology, Jiangsu Province Hospital of TCM, Nanjing University of Chinese \\ Medicine, Nanjing 210029, China. Email: wengui914@sina.com.
}

\begin{abstract}
Transcatheter arterial chemoembolization (TACE) has been widely used for the treatment of patients with inoperable hepatic carcinoma. Elemene has been confirmed to be a broad-spectrum antitumor drug. In this video, the authors introduced the procedure of TACE combined with elemene for a patient with hepatic carcinoma.
\end{abstract}

Keywords: Transcatheter arterial chemoembolization (TACE); elemene; hepatic carcinoma

Submitted Jul 23, 2018. Accepted for publication Aug 03, 2018.

doi: $10.21037 /$ tcr.2018.08.20

View this article at: http://dx.doi.org/10.21037/tcr.2018.08.20

\section{Introduction}

Hepatic carcinoma is the second most frequent cause of cancer death in men and the sixth in women worldwide (1). Surgical resection or transplantation has been considered only for a small number of patients with hepatic carcinoma because of the extent of disease or liver dysfunction. Transcatheter arterial chemoembolization (TACE) has been widely used for the treatment of patients with inoperable hepatic carcinomas (2,3). Elemene, a natural sesquiterpene extracted from the essential oils of a kind of Chinese herb-Curcuma aromatica Salisb, has been confirmed to be a broad-spectrum antitumor drug (4). In this video, the authors introduced the procedure of TACE combined with elemene for the treatment of a patient with unresectable hepatic carcinoma (Figure 1).

\section{Operative techniques}

A 75-year-old female patient with a liver tumor confirmed intrahepatic cholangiocarcinoma by biopsy, unresectable for her pulmonary insufficiency. Hepatic angiography was performed using 5-Fr angiographic catheters to assess the vascularity of the tumor. After super-selective catheterization of the tumor feeding artery with a microcatheter (Progreat, Terumo, Japan), elemene injection was infused into the tumor for more than 15 minutes. The infused dose of elemene injection $(300 \mathrm{mg})$ was determined based on the body weight and liver function of the patient, double diluted with $5 \%$ glucose injection. Then, an emulsion of oxaliplatin $(50 \mathrm{mg})$, epirubicin $(30 \mathrm{mg})$ and lipiodol $5 \mathrm{~mL}(1-2 \mathrm{~mL} / \mathrm{cm}$ diameter of the tumor) was injected carefully and slowly to prevent backflow. Until the feeding arterial flow stasis or the portal branches were appeared, little gelatin sponge particles were then used to embolize the tumor-feeding vessels completely. Hepatic angiography was performed again to confirm the treatment effect.

\section{Comments}

TACE has been proven to be effective to prolong the survival of the patient with inoperable hepatic carcinoma. Blood concentration in the tumor is significantly associated with the tumor response. Elemene injection can be infused into the feeding arteries of the tumor by using catheters accurately and safely. Combined with TACE, this combination therapy might support very high drug solubility locally and enhance effectiveness of the treatment for unresectable hepatic carcinoma. 


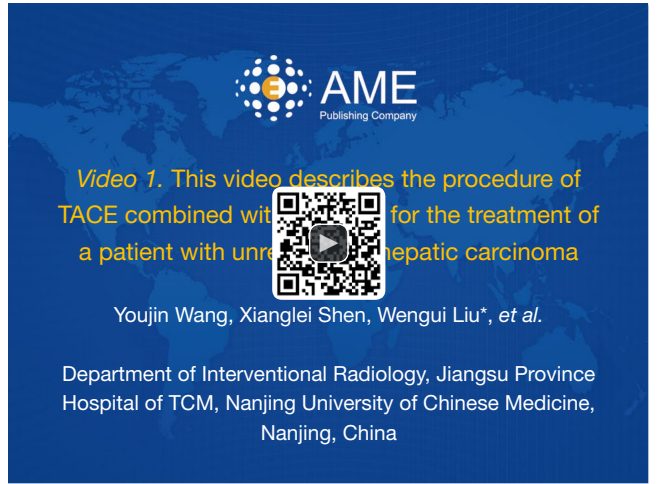

Figure 1 This video describes the procedure of TACE combined with elemene for the treatment of a patient with unresectable hepatic carcinoma (5). TACE, transcatheter arterial chemoembolization.

Available online: http://www.asvide.com/article/view/26846

\section{Acknowledgments}

Dr. Wengui Liu was awarded "Second Prize Winner" in the AME Liver Surgery/Interventional Surgical Video National Championship held in Nanjing, China on June 16, 2018.

Funding: None.

\section{Footnote}

Conflicts of Interest: All authors have completed the ICMJE uniform disclosure form (available at http://dx.doi. org/10.21037/tcr.2018.08.20). The authors have no conflicts of interest to declare.

Ethical Statement: The authors are accountable for all aspects of the work in ensuring that questions related to the accuracy or integrity of any part of the work are appropriately investigated and resolved. Written informed consent was obtained from the patient for publication of this manuscript and any accompanying images.

Open Access Statement: This is an Open Access article distributed in accordance with the Creative Commons Attribution-NonCommercial-NoDerivs 4.0 International License (CC BY-NC-ND 4.0), which permits the noncommercial replication and distribution of the article with the strict proviso that no changes or edits are made and the original work is properly cited (including links to both the formal publication through the relevant DOI and the license). See: https://creativecommons.org/licenses/by-nc-nd/4.0/.

\section{References}

1. Jemal A, Bray F, Center MM, et al. Global cancer statistics. CA Cancer J Clin 2011;61:69-90.

2. Llovet JM, Real MI, Montaña X, et al. Arterial embolisation or chemoembolisation versus symptomatic treatment in patients with unresectable hepatocellular carcinoma: a randomised controlled trial. Lancet 2002;359:1734-9.

3. Lo CM, Ngan H, Tso WK, et al. Randomized controlled trial of transarterial lipiodol chemoembolization for unresectable hepatocellular carcinoma. Hepatology 2002;35:1164-71.

4. Lin Y, Wang K, Hu C, et al. Elemene injection induced autophagy protects human hepatoma cancer cells from starvation and undergoing apoptosis. Evid Based Complement Alternat Med 2014;2014:637528.

5. Wang Y, Shen X, Huang S, et al. This video describes the procedure of TACE combined with elemene for the treatment of a patient with unresectable hepatic carcinoma. Asvide 2018;5:728. Available online: http://www.asvide.com/ article/view/26846
Cite this article as: Wang Y, Shen X, Huang S, Zhou J, Liu W. Transcatheter arterial chemoembolization combined with elemene for the treatment of hepatic carcinoma. Transl Cancer Res 2018;7(4):1164-1165. doi: 10.21037/tcr.2018.08.20 